This is a preprint version of: Franco Aixelá, Javier; Rovira-Esteva, Sara. 2015. "Publishing and impact criteria, and their bearing on translation studies: in search of comparability". Perspectives. Studies in Translatology. Special issue: Bibliometric and Bibliographical Research in Translation Studies, 23(2). Guest editors: Javier Franco, Pilar Orero and Sara Rovira-Esteva. DOI: 10.1080/0907676X.2014.972419

\title{
PUBLISHING AND IMPACT CRITERIA, AND THEIR BEARING ON TRANSLATION STUDIES. IN SEARCH OF COMPARABILITY
}

\author{
Javier Franco Aixelá* and Sara Rovira-Esteva** \\ *Javier Franco, Departamento de Traducción e Interpretación, Universidad de \\ Alicante (Spain); **Sara Rovira-Esteva, Departament de Traducció i d'Intepretació, \\ CERAO, Universitat Autònoma de Barcelona (Spain)
}

Corresponding author: Franco Aixelá, Javier - Javier.Franco@ua.es - Universidad de Alicante - Tel. 34 - 965692304 - Postal address: Javier Franco Aixelá / Dpto. de Traducción e Interpretación / Facultad de Filosofía y Letras / Universidad de Alicante / Campus de San Vicente del Raspeig - Apdo. 99 / 03080 - Alicante (Spain)

Rovira-Esteva, Sara - Sara.Rovira@uab.cat - Universitat Autònoma de Barcelona - Tel. 935813389 - Postal address: Sara Rovira-Esteva / Dep. de Traducció i Interpretació (Edifici K) / Plaça del coneixement / 08193 - Bellaterra (Spain)

Javier Franco - Bionote

Javier Franco Aixelá is a senior lecturer at the Department of Translation and Interpreting of the Universidad de Alicante (Spain), where he teaches literary translation, documentation and theory of translation.

For twelve years, he was a professional translator and as such has published about 40 books in Spain. 
He has coordinated the Translation Studies Ph.D. programme at the Universidad de Alicante, which was awarded with a "quality mention" by the Spanish Ministry of Education.

His research topics include the bibliography of translation, medical translation, and the manipulation of culture in translation. In the last decade, he has mainly focused his research on bibliographic and bibliometric matters, and he is the creator of BITRA (Bibliography of Interpreting and Translation), available online, and comprising (as of February 2014) over 58,000 records.

\section{Sara Rovira-Esteva - Bionote}

Sara Rovira-Esteva is a lecturer at the Department of Translation and Interpreting of the Universitat Autònoma de Barcelona (Spain), where she teaches Mandarin Chinese, translation from Chinese into Spanish, Chinese linguistics and research methodology. She has worked as a professional translator translating mainly Chinese films and contemporary Chinese literature. She coordinated the Translation Studies Ph.D. programme at the Universitat Autònoma de Barcelona, which was awarded with a "quality mention" by the Spanish Ministry of Education and currently holds the post of research coordinator at the Department of Translation and Interpreting.

Her research interests include bibliometric studies, translation studies, cross-cultural pragmatics, teaching Chinese as a foreign language and contrastive linguistics. She has authored four books and published numerous articles in journals on Chinese-Spanish/Catalan translation, Chinese linguistics and teaching Chinese as a foreign language. 


\section{Publishing and Impact Criteria, and their Bearing on Translation Studies. In Search of Comparability}

This paper attempts to problematize the current concept of quality as used in research assessment exercises, with special reference to the link often established with impact and the way this impact is measured in the form of citation counting. Taking Translation Studies as a case study, we will offer a two-level approach revealing both the existing macro- and micro-level biases in this regard. We will first review three key aspects related to the idea of the quality of publications, namely, peer review, journal indexing and journal impact factor. We will then pinpoint some of the main macro-level problems regarding current practices and criteria as applied to Translation Studies, such as WoK's journal coverage, citation patterns and publication format. Next we will provide a micro-textual and practical perspective, focusing on citation counts and suggesting a series of correction measures in order to increase comparability.

Keywords: quality, impact, translation studies, citation, journal indexes, bibliometrics

\section{Introduction: Quality as a problematic issue}

Measuring quality in research, as in translation, is certainly a tricky business, a domain in which everybody seems to have a common opinion until you start to delve into it and crucial differences start to crop out. In order to overcome the relativity of the whole issue, the current trend for assessment in publishing and accreditation is to resort to two basic pillars - peer review and the ranking of research derived from some kind of citation counting. Peer review would guarantee the unbiased selection of studies to be 
published, whereas citation counting would enable us to objectively gauge the results of the process, clearly separating relevant from junk research. Unfortunately, things are rather more complicated and the basically quantitative and popularity-based approach modern academy is using now is not without its own serious drawbacks. We will try to present some of them, always with special reference to their implications in Translation Studies (TS). To do so, we will offer a two-level approach revealing both the existing macro- and micro-level biases in this regard. In the first three sections we will first review three key aspects related to the idea of the quality of publications, namely, peer review, journal indexing and journal impact factor. Next we will pinpoint some of the main macro-level problems regarding current practices and criteria as applied to Translation Studies, such as WoK's journal coverage, citation patterns and publication format. The macro-level analysis will then be complemented with a micro-textual and practical perspective, focusing on citation counts and suggesting a series of correction measures in order to increase comparability. Finally, we will wrap up this paper with some conclusions.

\section{Peer review}

Nowadays one of the sacred pillars of scientific activity is undoubtedly peer review. Peer review is a ubiquitous system of academic assessment based on the principle that (normally) all experts in a given field share the same idea of quality and are always guided by objective criteria, especially when this kind of assessment is anonymous. However, as we shall see, members within the same discipline actually define quality and innovation in various ways and, by confidentially and critically assessing colleagues' work, reviewers act as gatekeepers and hold power over them. Although 
peer-review does not seem to be at stake, we think it necessary to put it to the test by summarising its main weaknesses and disadvantages.

In the first place, peer review is a controversial system within the scientific community, i.e. not everyone agrees it is the best way to guarantee quality, especially blind peer-review. According to Chubin \& Hackett (1990, p. 192), only 8\% of surveyed members of the Scientific Research Society agreed that "peer review works well as it is". Likewise, Drummond Rennie, deputy editor of the Journal of the American Medical Association, has declared: "we have no convincing evidence of its benefits but a lot of evidence of its flaws" (cited by Smith, 2010, p. 1), while Horrobin (2001) has concluded that peer review "is a non-validated charade whose processes generate results little better than does chance". In the same vein, Smith (2006, p. 116) has also asserted that "[s]tudies so far have shown that it is slow, expensive, ineffective, something of a lottery, prone to bias and abuse, and hopeless at spotting errors and fraud". In sum, many voices claim peer judgment is not reliable, peers do not agree with each other and do not remain consistent over time.

In the second place, as far as power relations are concerned, several authors agree that contributions to certain high-impact journals need to follow certain ideological strands and fit the scope of certain editorial leadership (Van Teijlingen \& Hundley, 2002; Macdonald \& Kam, 2007a, 2007b; Rovira-Esteva \& Orero, 2011, p. 246). This may imply “...the rejection of novel research, research which challenges mainstream theories, interdisciplinary research, multidisciplinary research or certain language pairs". Horrobin (2001) goes further by saying that: "[f]ar from filtering out junk science, peer review may be blocking the flow of innovation and corrupting public support of science". Therefore, the problem is that judgment of peers and the criteria 
they apply when reviewing papers or research outputs are not transparent enough and do not seem to be consistent or objective.

Last but not least, in the rather small, but highly diversified TS community, there is a patent quantitative lack of suitable reviewers. Since in some sub-areas of the discipline there may simply not be more than a handful of scholars competent enough for refereeing purposes (Gile \& Hansen, 2004, p. 2), enlisting reviewers to assess the quality of a series of manuscripts sent as a consequence of a call for papers can become a huge problem and there may be biases due to limitations of personal knowledge of peers or to their majority belonging to a certain school of thought.

\section{Journal indexing}

When submitting research outputs for assessment we know that value is placed basically on publications in indexed journals, that is to say, publications that appear in the ISI databanks (now Thomson Reuters' Web of Knowledge) or similar databases. In order to specify the effective repercussion of someone's research, consideration is given whenever possible to the impact ratio of the publications and the number of citations received for each article. These criteria pose several problems to quality assessment in the Humanities in general, and in TS in particular, namely: a) the concept similar databases; b) the way the impact factor is measured; and c) the way citations are selected and collected. Now we are going to discuss these three tricky aspects in detail.

When scholars are told they should publish in journals included in ISI databanks or similar, some feel to be at a loss. TS-oriented ISI journals are really scarce, and "similar" is too ambiguous a word to use in this context. It seems impossible to know whether it refers to the fact that these alternative databanks should be highly selective with the journals they index or rather that they have to provide a ranking of the journals 
selected according to given quality criteria. Amongst the international indexes usually taken as alternative options to the Web of Knowledge (WoK), we find Bibliographie Linguistique (BL), Francis, Historical Abstracts (HA), International Bibliography of Periodical Literature (IBZ) and Scopus, amongst others. However, except Scopus with its Scimago Journal and Country Rank (SJR), none of them offers a ranking of journals. Consequently, it seems that the mere inclusion of a journal in one of these indexes should be considered as evidence of its scientific quality and popularity amongst researchers and bestow such a journal the category of "indexed journal", i.e. enough to achieve a positive assessment. Unfortunately, "indexed journal" is usually understood exclusively as ISI-indexed journal by default. The reason why it is important to clarify what is actually meant by "indexed journal" is because WoK only covers around $10 \%$ of the living TS journals we find in specialized databases, such as BITRA (Bibliography of Interpreting and Translation) or RETI (Journals of Translation and Interpreting) ${ }^{1}$. There are other international indexes that cover many more TS journals than ISI, such as Scopus (19\%), Linguistics and Language Behavior Abstracts (25\%), ERIH (28\%) and Google Scholar's h-index (37\%).

\section{Journal Impact Factor}

Journal Impact Factor (JIF) is a product of Journal Citation Reports (JCR), part of Thomson Reuters, who began to publish it yearly starting from 1975. The JIF is a metric calculated through an algorithm based on the total number of citations that have been accrued by articles in a journal over a two-year period after publication. If we take the

\footnotetext{
${ }^{1}$ Both are open access. RETI is available at http://www.bib.uab.cat/human/acreditacions/planes/publiques/revistes/eti.php?area=eti\&men uidioma=eng, whereas BITRA is to be found at: http://dti.ua.es/en/bitra/introduction.html
} 
total citations for that journal over that biennium and divide it by the number of citable articles published in that same two-year period what you get is the JIF. These metrics are primarily of interest to publishers and journals, and originally were not designed to assess the quality of work by individual authors but in order to allow libraries to select what journals to subscribe (Garfield, 1999, p. 979). Even so, they are often used in evaluation and appraisal exercises of departments and individual academics - a highly unfair and debatable practice. Although there have been many criticisms of the JIF and other metrics, they are still being used, especially in the experimental sciences and increasingly in the Humanities. Below, we will try to show why this trend in research metrics is clearly inadequate.

\section{WoK's journal coverage}

The European Science Foundation (ESF) denounced that Thompson Reuters's citation indexes should not be used by European academic authorities because they have unsatisfactory coverage of European Humanities research (European Science Foundation, 2009: 4). This is what motivated the creation of the European Reference Index for the Humanities (ERIH), published in 2007-2008. Nevertheless, ERIH's list hardly improved the coverage of TS journals compared to WoK, as in its 2011 revised version it only covers a total of 31 titles -- the paradox being that ERIH was created as an alternative to JCR but ESF claims it is not intended to be a bibliometric tool or a ranking system. However, despite the fact that only $18 \%$ of titles covered by WoK belong to Arts \& Humanities (Moed, 2005, cited by Torres-Salinas, Delgado LópezCózar, Jiménez-Contreras, 2009, p. 24), Thompson Reuters' products are still the bibliometric tools par excellence used in Europe for assessment purposes in the Humanities. Next, we will explain in detail how this practice affects TS. 
WoK has two products seemingly relevant to TS: the Arts \& Humanities Citation Index (AHCI), covering 1,705 publications and 4.6 millions of registers, and the Social Sciences Citation Index (SCCI), covering 3,063 publications and 7.9 millions of registers (Web of Science, 2014). Despite these impressive figures, WoK does not cover even a majority of all existing journals, and only around $10-12 \%$ of candidate titles are accepted for coverage (Testa, 2012). The rationale for being selective is twofold: economy and pragmatism. Since according to Bradford's Law a relatively small number of journals publish the majority of "significant" scholarly results, there is no need to index them all (Garfield, 1979, cited in Testa, 2012).

Many factors are taken into account when evaluating journals for coverage in WoK, ranging from the qualitative to the quantitative. Amongst the factors issues considered we find the journal's basic publishing standards, including timeliness, its editorial content, the international diversity of its authorship, and the citation data associated with it. No one factor is considered in isolation, but by combination and interrelation of data. According to Testa (2012), the following two specificities are taken into account as far as the Arts \& Humanities are concerned: i) citation patterns do not necessarily follow the same predictable pattern as citations to Social Sciences and Natural Sciences articles, and ii) journal articles frequently reference non-journal sources. It must be noted that Testa (2012) also recognizes that: "English-language text is not a requirement in some areas of Arts \& Humanities scholarship where the national focus of the study precludes the need for it". Indeed, out of the 58,000+ entries included in BITRA as of February 2014, English-language texts amounted to 29,084 (50\%). This means that English is obviously the most used language in TS, but that it amounts only to about half of everything that is published, probably less so, since it is also logical to suppose that, generally speaking, non-English texts will find it more difficult to come 
into this database's radar. Thus, focusing "on journals that publish full text in English" (Testa, 2012) involves ignoring more than half of the actual research production without even taking the trouble of justifying these exclusions in terms of quality.

If we abandon journal level to move down to article level, the need for available and usable bibliometric tools adapted to TS research culture turns to be even more urgent in a bibliometric world apparently very dependent on the evaluator's criteria. For example, the most cited journal article in BITRA (91 citations recorded), Mona Baker's "Corpora in Translation Studies: An Overview and Suggestions for Future Research" (1995) has 619 citations in Google Scholar (GS), and no citations at all neither in Scopus nor in WoK. Many of the highest impact papers within our discipline do not even appear in Scopus or WoK, and the articles top authors have published in JCR's indexed journals have only a few citations or none as covered by WoK. For example, Baker (2010) and Venuti (2009), two of the leading scholars in the discipline, most cited articles in WoK, have only 13 and 6 citations, respectively, whereas Baker (1995) had already over 90 citations recorded in BITRA and Venuti's "Translation and the Formation of Cultural Identities" (1994) had already 20 citations recorded in that same database.

There are separate editions of JCR for the Sciences and the Social Sciences, but there is no JCR for Arts \& Humanities. The Social Sciences edition contains only 1,768 titles, i.e. it does not contain all the journals covered by SCCI. Since different specialities exhibit different ranges of peak impact, JCR provides subject category listings. In this way, journals may be viewed in the context of their specific field. Language and Linguistics are the nearest subject categories we can find to TS both in the AHCI and SCCI, but these two indexes only cover $16(14 \%)$ and $11(9.5 \%)$ journals, respectively, of a total of 112 TS scholarly live titles we have listed to carry out this 
piece of research (see appendix). Even after applying these very restrictive filters to TS journals, none of the few TS titles included in the Social Science Edition of the JCR can be considered high-impact journals within this framework, since they are mostly in the third and fourth quadrants. Paradoxically, within the TS community, these are the "most wanted" journals, since they are "indexed", they are generally considered the most prestigious, and publishing in them may give scholars the key to a successful assessment as long as assessment is carried out by experts from our field.

If Thompson Reuters' products are the only indicators to be taken into account in TS assessment, can this approximately $10 \%$ of selected titles be considered highranking journals despite not being in the first two quadrants in the Language and Linguistics subject category? What can the other $90 \%$ aspire to? Can their exclusion from Thompson Reuters' list be a reliable indicator to consider them lacking international quality standards? Do they all deserve extinction? The answer to the last two questions is absolutely no, not only because Thomson Reuters itself makes clear that meeting a series of quality criteria is not enough for journals to be included into WoK, but also because we know by experience and sheer logic that many of these journals are fulfilling the need for dissemination of quality research results within the TS community and their wholesale disappearance would involve the end of TS as an autonomous discipline. All in all, it seems obvious that the Humanities in general and TS in particular needs its own journal ranking systems if they are to be significant at all.

\section{Citation patterns: a question of quantity and quality}

There are many factors affecting both the quantity and the type of citations developed in a research field. In this section, we will review those aspects that leave TS in a position of disadvantage with respect to other fields, even within the Humanities. 
The number of specialists in a particular research field and, consequently, the volume of publications within the field (Guerrero, 2001, p. 59) are key factors to be taken into account when assessing impact through citations. According to Garfield (2007, p. 67), the size of the field generally increases the number of "super-cited" papers, and it is obvious that TS encompasses a relatively small community compared to Linguistics or Literature, the fields in which our interdiscipline is usually subsumed in existing rankings. The rate at which research on a given topic progresses can also have an impact both on the number of citations and citation windows. Using quantitative citation data to measure impact is thus only meaningful in the context of journals in the same general discipline, because smaller fields like TS do not generate as many articles or citations as larger fields. Thus, including TS in the general field of Linguistics can only mean that TS journals are condemned to the lower quadrants for sheer lack of citers in comparison with mainstream linguistics.

It is widely acknowledged (Testa, 2012; Giménez-Toledo \& Torres-Salinas, 2011) that in the Arts \& Humanities it may take a relatively long time for an article to attract a meaningful number of citations. In a study focusing on TS, Franco Aixelá (2013, p. 22) stated:

It seems reasonable to conclude that in TS, works take their time to reap impact, apparently much longer than in the hard sciences. Applying to TS the 2-year impact window accepted by so many academic authorities means discarding the real impact, which tends to start to appear about 5 years after publication.

If we take BITRA as a corpus of study, the 50 most cited publications and any publication with 10 or more citations starts seriously accruing them 5-10 years after publication. At the time of writing this paper BITRA included 566 TS-oriented journal articles launched in 2012 and only 45 (8\%) had any citation; out of the 848 articles 
published in 2008, 217 (26\%) had at least one citation; while out of the 876 articles issued in 2003, $305(35 \%)$ had at least one citation. These numbers show that TS journals have significantly longer citing half-lives (number of retrospective years required to find $50 \%$ of the cited references) than those for journals in Linguistics.

\section{The publishing format: books vs. journals}

Testa (2006, p. 137) observes that Arts \& Humanities journal articles frequently reference non-journal sources (e.g., academic books, musical compositions, works of art and literature). Regarding the hierarchy of importance of citation type in the Humanities, the European Science Foundation (2009, p. 3) claims that books are of primary importance, while peer reviewed journal articles account for less than $1 / 3$ of outputs. Previous bibliometric studies have empirically quantified these differences in the field of TS. For example, Rovira-Esteva \& Orero (2011, p. 242) examined 326 reference lists out of a corpus of 5 ISI-indexed journals. They grouped references in four main categories: articles published in academic journals (both in paper and electronic format); book chapters (including prologues and introductions); whole books (both being primary and secondary sources); and other (chiefly consisting of $\mathrm{PhD}$ theses, MA dissertations, proceedings, internet sites, technical reports and press articles). They concluded that books are by and large the most cited kind of contribution in the bibliographies they looked at, with an average percentage approaching the $50 \%$ mark. As regards journal articles and book chapters referenced, both surpassed $20 \%$ ( $21 \%$ and $20.2 \%$, respectively). Finally, other kinds of contributions, although much smaller in number, also represented $9.5 \%$ of the total number of references analysed. If, as their analysis highlighted, the main mode of research dissemination in TS are books 
and book chapters $(69.3 \%)$, we wonder why they are not regarded equally as highly as journal articles in quality assessment processes.

In the same vein, Franco Aixelá (2013, p. 23) has shown that, amongst the 51 most cited works in TS as covered by BITRA, there are 47 books $(92.2 \%), 4$ chapters (7.8\%) and no journal articles. With over 68,000 citations already mined and assigned to the corresponding cited publications by December 2013, 35\% of the 58,024 entries BITRA included by then had received at least one citation each. Classifying them by format, $49 \%$ of the books (including edited volumes, which are less liable to be cited) had at least one citation, whereas only $33 \%$ of the journal articles and $31 \%$ of the book chapters had received any citation as recorded by BITRA. As we increase the threshold of minimum citations, the (dis)proportion between books and journal articles grows accordingly. Thus, $52 \%$ of the publications with at least 10 citations recorded in BITRA are books, whereas $22 \%$ are journal articles and the same percentage $(22 \%)$ are book chapters. With 50 recorded citations as the minimum threshold, $85 \%$ were books, $10 \%$ were book chapters, and 3\% were journal articles. Therefore, it seems there is strong evidence that in TS, books are read much more and cited more often than other publication types. All these figures illustrate how necessary it is for TS to have its own bibliometric tools to assess the impact of books and book chapters, which is much greater than the one accrued by journal articles, in a reliable and meaningful way.

By the end of 2011 Wok launched the Book Citation Index. It is currently available from 2005 to the present, covering almost 50,000 titles, with 10,000 new books added each year. Included titles correspond $40 \%$ to Social Sciences, $18 \%$ to Arts \& Humanities and $42 \%$ to the Natural Sciences (Thomson Reuters, 2013, p. 3). Although we have found some volumes from John Benjamins' series Benjamins Translation Library amongst the indexed books, the number of titles selected is, once 
again, neither significant nor representative of the whole production in TS (there are at least over 8,000 books focusing on TS, according to BITRA). Generally speaking, some of the problems detected with the Book Citation Index are: selected publishing houses are mainly commercially oriented, publish almost solely in English, and many European prestigious publishers are poorly represented or absent (Torres-Salinas, RobinsonGarcía, Jiménez-Contreras, Delgado-López-Cózar, 2012). As far as Scopus is concerned, at the moment of writing this article it covered around 25,500 books, 750 book series, and 26,000 individual book series volumes, accounting for only $1 \%$ of entries (Elsevier, 2014). However, we have not found a single volume devoted to TS.

If we consider that out of over 58,000 TS-oriented entries included in BITRA as of February 2014, journal articles accounted for some 25,000 (43\%), it seems obvious that traditional impact-measuring systems are basically marginalizing more than half of the academic production in our area.

The fact that no comprehensive bibliometric indexes have been developed for books and that, in spite of attracting many more citations, books are nowadays rated lower than articles in most cases may probably explain why journals, especially those listed in Thomson Reuters, are experiencing an increase in submissions, which has resulted in longer lag times between acceptance and final publication of a manuscript, thus making it even more difficult to accrue citations within a two-year period.

In sum, from a macro-textual perspective the possibilities of accruing (recognized) citations depend on a number of factors, such as kind of publication, language of publication, accessibility to documents, place of publication and type of publisher, all of them quite alien to the intrinsic quality of the work itself.

\section{A micro-textual perspective}


In this section we will perform a practical analysis to illustrate the citing odds each publication has from a more individual or micro-textual perspective. Our focus will be on confirming whether the number of citations received is a reliable index of quality or, if this is not so, what kind of correction measures could be applied in order to obtain more balanced and representative bibliometric patterns than the ones we have been commenting above.

To this aim, we will use data obtained from BITRA (Bibliography of Interpreting and Translation) as of December 2013. This database has the advantage of exclusively focusing on TS, thus enabling us to perform comparisons between really similar publications. For instance, with this tool it is possible to directly perform a diachronic comparison of the impact accrued only by the 474 journal articles written in English and dealing with legal translation as their main subject, excluding all other publications featuring any other language, subject or format. We could then compare this impact factor with the one obtained by analysing the 440 chapters included in edited volumes, or with the 127 books featuring the same language and central subject as the journal articles previously analysed. After having thus isolated format as the only variable, this analysis should enable us to obtain meaningful conclusions regarding the influence of format on impact. To our knowledge, no other tool makes it possible to gather in such a flexible and discriminative way comparable groups of academic publications in TS at the same time that it comprises a considerable sample of citations. There is no room here to describe in detail this open-access database (for further information, cf. BITRA's website). For our present needs, suffice it to say that as of December 2013, BITRA comprised 58,000 entries with information about as many TSoriented publications, and that by this same date we had already mined the citations 
included in 5,011 academic TS publications, resulting in 68,174 citations assigned to the corresponding cited publications.

Above, we have seen some of the main issues that explain why the rankings usually applied in the measurement of the impact of a given academic publication are especially inadequate in Humanities in general and in TS in particular. We would now like to exemplify these distortions, considering the above-mentioned issues, and adding to them some micro-textual issues factors that result in different chances of being cited within the discipline. Thus, to the already mentioned factors of the popularity of the discipline in comparison with others such as Linguistics and of the format (book, journal, etc.) we will add the following variables, and then check if they are really influential regarding the number of citations obtained and, thus, whether they cause a distortion that forbids equating impact with quality, at least in the way impact is currently measured:

(1) The popularity of the object of study: within the same discipline, in parallel with the already mentioned above popularity of a given discipline, there are always subject matters that attract more researchers than others. Logically, the more researchers paying attention to a given issue, the greater the chances for a publication to be cited -and vice versa. Let us just think of the potential citations of two studies with the same quality, one about the translation of Shakespeare and the other about the translation of a local internationally-unknown author.

(2) The sub-genre: In the same vein, the number of potential readers (and citers) of a case study will be smaller than those interested in a general overview, such as the one provided by a handbook or by a state of the art. 
(3) Distribution potential: the same study published by a powerful commercial publisher or by a small university will have very different chances as to the size of its readership.

(4) Author's self-citations: It is normal for authors to cite themselves, even if only not to repeat what they have already said elsewhere. It is not so normal to admit that self-citations are indicative of impact.

(5) Confusion between container and contents: the impact of journal articles is usually gauged as a reflection of the impact of the journal, as if both were equivalent, when both logic and observation tell us that the same journal may have articles with hundreds of citations and others with very few or none.

\section{Some examples of why current models do not work}

Let us now see a couple of examples showing the distorting effect of the most influential among these factors. According to BITRA, the most cited article in the journal Target is "Corpora in Translation Studies: An Overview and Suggestions for Future Research", published by Baker in 1995. By December 2013 BITRA had detected 91 citations to this article. At the same time, in BITRA there were 119 articles also from Target (as many as 14 of them previous to year 2000) with no citations detected by us at

all. To say that these articles with no citations have had the same impact as Baker (1995) just because they have been placed in the same journal is hardly logical.

The same author has an article entitled "Corpus-based Studies within the Larger Context of Translation Studies" (Baker, 2002). This text is clearly generalist and it is in English, but it was published in the journal Génesis, fostered by the ISAI (Instituto Superior de Assistentes e Intérpretes, located in Oporto). This article had no citations collected in BITRA. If we take into account that it was written by the same author, with 
the same subject matter and approach as Baker (1995), it is logical to suppose that both will bear at least a similar interest, but after more than 10 years since its publication we had not found even one citation to it. This seems to clearly back up our hypothesis - that the amount of citations can be considered meaningful only if the comparison is made between publications with similar chances to be cited, but that the lack of them can very likely mean nothing as regards quality.

Here is another example, now combining language and object of study. Theo Hermans is a prestigious scholar who regularly writes in English and in Dutch, and addresses both general topics and case studies. For instance, Hermans (1999) has a book in which he explains polysystems and descriptivism with 124 citations detected in BITRA as of December 2013. Nevertheless, when we look for the studies of this same author featuring "Netherlands" as a subject matter we find 19 publications, two thirds of which (12) had no citations yet in BITRA. The data show that, in terms of impact, it is much more profitable to address universal or general topics, that focusing on a local subject means paying a penalty for the researcher in terms of impact, and that quality has nothing to do with this. If we dig a bit deeper we can shed even more light. Out of the 19 essays by Theo Hermans with "Netherlands" as a subject matter only 7 had been cited so far according to records in BITRA for December 2013, and only 2 of these had more than one citation as yet. What is the difference between these 2 and the other 17 with 1 or no quotations? As is only to be expected, these two are the only ones which are not real case studies, although something related with the Netherlands is part of them. The first one (Hermans, 1996) had 40 citations in BITRA and deals with "The Translator's Voice in Translated Narrative", an article on the translator's presence in which a Dutch work is used as an illustration, but not as an object of study in itself. The other one ("On Translating Proper Names, with reference to De Witte and Max 
Havelaar", published in 1988) had 10 citations and is really a generalist study on the translation of names, once again using the same Dutch literary work as a source of illustrations. As soon as a reputed researcher such as Theo Hermans focuses his research on local matters and does not apply a generalist approach, his possibilities of being cited plummet. It is to be expected that the same does not happen with the quality of his research, although one would think that was the case if only the number of citations received was taken into account.

Regarding language as vehicle of communication, suffice it to say that the average of citations for Hermans' 13 publications in Dutch (1988-2004) is 0.4 ; the average of citations for his 71 publications in English (1982-2012) is 9.3 citations per publication. The moral of this story is clear and actually there are many authors from non-English speaking countries who try to publish in English, aware of its dissemination and impact potentials.

These two examples should be enough to prove that impact and quality belong to different dimensions and that it is reasonable to suppose that the chances of being cited partly depend on quality but that they also depend -and to a greater extent- on the circumstances in which they have been published. In other words, it does makes sense to admit that the most cited publications will very likely be especially interesting for researchers, but it is deeply mistaken to suppose the opposite, i.e. that the lack of citations is a sign of the absence of interest. Factors such as the absence of a numerous pool of readers with an interest in a given subject matter, lack of accessibility for language or dissemination reasons, or lack of mining systems able to collect the less visible quotations, perfectly explain away the lack of citations in numerous instances. To act as if all publications were launched with the same chances of being cited and that only quality marks the difference is an important bibliometric confounder. Moreover, it 
is not only very unfair to use this criterion to assess academic careers, but it is also a dangerous practice for science in general and the Humanities in particular, since it involves the indirect promotion of mainstream subjects to the detriment of local, minority or innovative subjects.

According to the generally widespread vision of impact, the disseminating book on descriptivism written by Hermans (1999, with 124 citations collected in BITRA) would be an example of excellent research, whereas all his research production in Dutch (13 publications, with a total of 5 citations jointly mined for all of them) would bear no academic interest at all. Given this scene, if we wish citation-based bibliometry to be really indicative of the interest of a given publication, we need to introduce correction factors into the equation, factors allowing us to compare really comparable publications as regards impact. We will now put forward some examples of this kind of corrections, for whose implementation we need to have specialized databases making really visible most of the research production in a given discipline and enabling us to classify them into homogeneous -i.e. really comparable in citation terms- groups of publications.

\section{An illustration of a different way to analyse impact}

Our intention here is to illustrate the application of some of the abovementioned factors when grouping publications to increase their comparability. Our aim is to ensure that their impact in terms of citations received in a given period is really significant. Once again, we will use BITRA as our source of data, thus discarding two important confounders from the start: the popularity of the discipline (BITRA only collects studies in TS) and authors' self-citations (BITRA does not mine them). Further information can be obtained in Franco Aixelá (2013) or in the database itself. 
We will then put forward an example of a bibliometrically homogeneous group in which the number of citations can really be considered to be indicative of quality or, at the very least, of a high degree of potential interest within similar citability conditions. In line with the journal-oriented contents of this article, we have chosen for this analysis to do a comparative study of the academic popularity of all journal articles dealing with the teaching of translation, written in English and published in the 5 most cited TS journals according to Table 1.

\section{INSERT TABLE 1 HERE}

It is noteworthy that in this table there is a considerable difference regarding the potential citability of TS journals, even after restricting our analysis to the 10 most cited ones. Thus, the two most cited journals receive between 5 and 12 times as many citations as the ones which occupy positions 6-10. The difference with the less cited journals is even greater. For an example of peripheral journals, in a recent study (Franco Aixelá, 2012) focusing on the 2001-2010 period for TS journals published in Spain, the aggregated mean impact factor was 0.25 citations per article, i.e. 18 times less than the two most cited journals according to this article.

Thus, in order to maximize comparability, we will reduce our study to the group of the 5 most cited journals, all of which have an average of over 1 citation per article for the 1995-2010 period according to records in BITRA as of December 2013.

Adding all articles and special issues for 1995-2012 in the 5 most cited TS journals (The Translator, Target, Interpreting, Across Languages \& Cultures and Meta) we obtain a total of 1,608 items, 208 of which deal with didactics and 147 of which also meet the language condition, i.e. being written in English. 
Almost all the other articles in this group are written in French, due to the inclusion in this analysis of Meta, the only one of the 5 most cited TS journals frequently featuring articles in any language other than English. Another evidence of our theses is that 14 articles out of 147 written in English $(9.5 \%)$ have more than 10 citations, whereas only one (out of 61 written in French, i.e. 1.5\%) has more than these same 10 citations. To round up this comparison, it is also important to note that there are 7 articles in Meta on TS didactics and written in English for which we have detected 10 or more citations. Either studies written in French are systematically worse than those written in English or it becomes necessary to accept that, in comparable conditions, language is a factor that promotes or discourages citations with nothing to do with quality.

In order to make the group completely comparable according to the criteria we have presented above, we only need to separate case studies or studies addressed to particular TS fields from general-interest essays. To begin with, it seems a good idea to draw a great dividing line between those dealing with written translation and those dealing with interpreting, since in principle they cover different fields and, thus, appeal to different (and differently sized) groups of scholars. If convenient for research, we could also make subgroups within both fields in order to discover which sub-areas are more popular within TS. As can be seen, the avenues of bibliometric research opened by this approach are very broad.

Out of the 147 English items on the didactics of TS, there are $42(28 \%)$ addressing the teaching of interpreting, a figure which is quite close to the global percentage $(22 \%)$ of interpreting didactics in TS teaching in general as reflected in BITRA. Incidentally, BITRA also shows that out of the 52,400 entries not dealing with interpreting, 5,717 deal with didactics. This means that $11 \%$ of the publications on 
written translation deal with didactics, whereas the figure rises to $22 \%$ for interpreting. This seems to indicate that the interest shown by interpreting scholars in didactics doubles the one shown towards didacties teaching matters in written translation in general, enabling us to put forward the hypothesis that interpreting it is a more practically-oriented field of research.

Out of the 42 English-language articles on the teaching of interpreting, 10 deal with experiences in particular countries or language combinations, amounting to what we have termed case studies. These 10 articles feature a total of 7 citations $(0.7$ citations per article). The other 32 articles have 156 citations (4.9 citations per article). The difference is clear and needs no further comments, except perhaps to insist that in this stage of citation mining by BITRA, being a case study and having very few or even no citations is no evidence of lack of quality but a normal consequence of a local or specific approach. Furthermore, it is very likely that the 6 articles in this sub-group addressing the teaching of interpreting in China or Korea have received many citations which are currently invisible to BITRA (and to the other current indexes) given our difficulty to process academic publications in non-Latin writing systems.

If we limit ourselves to the English-language general-interest articles on the teaching of interpreting included in these 5 journals, we discover that two of them (Ericsson, 2000 and Pöchhacker, 2001) have 14 and 18 citations (1.1 and 1.5 citations/year), respectively, whereas none of the others reaches 10 citations and, as a group, have an average of 4.9 citations per article. Thus in conditions of real comparability, Ericsson (2000) and Pöchhacker (2001) are really outstanding and it is reasonable to state that they will most likely be very interesting, if not outright pieces of high-quality research. Similarly, it would be reasonable to suppose that the 5 articles in 
this group with 0-1 quotations are probably less interesting than their more cited counterparts, something which would not be possible to state regarding the case studies.

If we had more room in this article and wanted to compare these articles with their counterparts from lesser cited journals, we would need to establish a new average of citations for a new homogeneous group, classify the articles between those with a general approach and case studies, and establish a new citation average for both groups of articles in order to estimate the new meaningful citation pattern, which would no doubt be lower than the one we have seen for the group of most cited journals.

We could also advance in our analysis with a parallel study of the didactics of written translation but the example we have developed in some detail should be illustrative of what we mean when we speak about the need to establish meaningful comparisons instead of acting as if all publications had basically the same citing odds, and quality was the only factor needed to explain why some have more citations than others.

\section{Conclusions}

In this article we have shown that quality in research is not guaranteed by peer review, that journal indexing is not a good way to sift out quality journals from the rest -at least not in a relatively small humanistic discipline such as Translation Studies-, and that impact in the form of citations is not directly related to the intrinsic quality of the contribution when ad hoc comparable groups are not used. The concept of impact as currently applied in assessment exercises is a very narrow one and has many flaws. Nevertheless, nowadays there exist other bibliometric tools that are not only access free, but which also can provide a more accurate picture of the real impact of a research document. 
Additionally, there are many things we can do to increase the impact of our research outputs at different stages of the process. At the very beginning, when selecting the subject and language of the paper, opting for the type of document where we are going to disseminate the results, etc. When time arrives to undergo a research assessment, we can also help the assessors' task by providing them with a wealth of informed data about the relative quality of the journals (or books) where our text has been published, as well as the impact of our publications.

We hope that the bibliometric virtues of searching for real comparability are clear by now. It is also necessary to acknowledge that, from a logistic point of view, our approach is much more complex than the mere decontextualized rankings have the academia is using now. This is so because our bibliometric system demands introducing qualitative considerations into the equation and refining the taxonomy of academic publications in order to establish really homogeneous groups which pay the necessary attention to very influential variables such as the degree of specificity of the object of study or the dissemination potential of the container, all of which involves a laborious individual classification of the publications to be analysed. Likewise, it would be necessary to enroll experts in bibliometric analysis to determine the significant means in each case, something we would like to address in the future.

\section{References}

- Baker, M. (1995). Corpora in Translation Studies: An Overview and Suggestions for Future Research. Target, 7(2), 223-243.

- Baker, M. (2002). Corpus-based Studies within the Larger Context of Translation Studies. Génesis, 2, 7-16. 
- Baker, M. (2010). Interpreters and Translators in the War Zone Narrated and Narrators. Translator, 16(2), 197-222.

- Chubin, D. R. \& Hackett E. J. (1990). Peerless Science, Peer Review and U.S. Science Policy. New York: State University of New York Press.

- Elsevier. (2014). Content Overview Scopus. http://www.elsevier.com/online$\underline{\text { tools/scopus/content-overview }}$

- Ericsson, K. A. (2000). Expertise in Interpreting: An Expert-Performance Perspective. Interpreting (International Journal of Research and Practice in Interpreting), 5(2), 187-220.

- European Science Foundation. Humanities Unit. Increasing visibility for a multifaceted humanities research in Europe - the ERIH approach, 2009 $<$ http://www.esf.org/index.php?eID=tx_nawsecuredl\&u=0\&file=fileadmin/be_user/ research_areas/HUM/Documents/NETWORKS/ERIH_presentation2009.pdf\&t=130 6926438\&hash $=02356 a 85$ ba8ddd4b569e4cbbc404880d $>$

- Franco Aixelá, J. (2012). A critical overview of the Translation Studies journals published in Spain. In I. García Izquierdo \& Esther Monzó (Eds.) Iberian Studies on Translation and Interpreting (pp. 339-360). Oxford: Peter Lang.

- Franco Aixelá, J. (2013). Who's who and what's what in Translation Studies. A preliminary approach. In C. Way; S. Vandepitte; R. Meylaerts \& M. Barthlomiejczyk (Eds.) Tracks and Treks in Translation Studies. Selected papers from the EST Congress, Leuven 2010 (pp. 7-28). Amsterdam: John Benjamins.

- Franco Aixelá. J. (2001-2014). BITRA (Bibliography of Interpreting and Translation). Available at: http://dti.ua.es/en/bitra/introduction.html 
- Garfield, E. (1999). Journal impact factor: a brief review. Canadian Medical Association Journal, 161(8), pp. 979-980. http://www.garfield.library.upenn.edu/papers/journalimpactCMAJ1999.pdf

- Garfield, E. (2007). The evolution of the Science Citation Index. International microbiology, 10, 65-69. DOI: 10.2436/20.1501.01.10.

- Gile, D. \& Hansen, G. (2004). The editorial process through the looking glass. In H. GydeK K. Malkmjær \& D. Gile (eds). Claims, Changes and Challenges in Translation Studies (pp. 297-306). Amsterdam: John Benjamins.

- Giménez-Toledo, E. \& Torres-Salinas, D. (2011). Book citation index: una nueva historia (adaptada) sobre bigsciencey littlescience. Anuario ThinkEPI, 5.

- Guerrero, R. (2001). Misuse and abuse of journal impact factors. European Science Editing, 27(3), 58-59.

- Hermans, T. (1988). On Translating Proper Names, with reference to De Witte and Max Havelaar. In Wintle, M. (Ed.) Modern Dutch Studies (pp. 11-28). London: Athlone.

- Hermans, T. (1996). The Translator's Voice in Translated Narrative. Target 8(1), 23-48.

- Hermans, T. (1999). Translation in Systems. Descriptive and System-oriented Approaches Explained. Manchester: St. Jerome.

- Horrobin, D. (2001). Something Rotten at the Core of Science? Trends in Pharmacological Sciences, 22(2). Also available at http://www.whale.to/vaccine/sci.html and http://post.queensu.ca/ forsdyke/peerrev4.htm 
- Humanities Library. Department of Translation and Interpreting. Universitat Autònoma de Barcelona. (2014). RETI (Revistes dels Estudis de Traducció $i$ Interpretació). Available at: www.uab.cat/libraries/reti

- Macdonald, S. and Kam, J. (2007a). Aardvark et al.: quality journals and gamesmanship in management studies. Journal of Information Science, 33(6), 702717.

- Macdonald, S \& Kam, J. (2007b). Ring a ring o' roses: quality journals and gamesmanship in management studies. Journal of Management Studies, 44(4), 640655.

- Pöchhacker, F. (2001). Quality Assessment in Conference and Community Interpreting. Meta 46(2), 410-425. Available at: http://www.erudit.org/revue/meta/

- Rovira-Esteva, S. \& Orero, P. (2011). A Contrastive Analysis of the Main Benchmarking Tools for Research Assessment in Translation and Interpreting: The Spanish Approach. Perspectives. Studies in Translatology, 19(3): 233-251.

- Smith, R, (2006). The trouble with medical journals. Journal of the Royal Society of Medicine, $\quad$ 99, $116 . \quad$ Available at: http://jrsm.rsmjournals.com/content/99/3/115.full.pdf)

- Smith, R. (2010). Classical peer review: an empty gun. Breast Cancer Research, 12(4), S13. Available at: http://breast-cancer-research.com/content/12/S4/S13

- Testa, J. (2006). The Thomson Scientific journal selection process. International Microbiology, 9, 135-138.

- Testa, J. (2012). The Thomson Reuters Journal Selection Process. Available at: http://wokinfo.com/media/essay/journal_selection_essay-en.pdf

- Thomson Reuters. (2013) Thomson Reuters Web of Knowledge. Available at: wokinfo.com/media/pdf/SSR1103443WoK5-2_web3.pdf 
- Torres-Salinas, D.; Delgado López-Cózar, E. \& Jiménez-Contreras, E. (2009). Análisis de la producción de la Universidad de Navarra en revistas de Ciencias Sociales y Humanidades empleando rankings de revistas españolas y la Web of Science. Revista Española de Documentación Científica, 32(1), 22-39. DOI: 10.3989/redc.2009.1.673.

- Torres-Salinas, D.; Robinson-García, N.; Jiménez-Contreras, E. \& Delgado LópezCózar, E. (2012). Towards a 'Book Publishers Citation Reports'. First approach using the 'Book Citation Index'. Revista española de Documentación Cientifica, $35(4), 615-624$.

- Van Teijlingen, E. \& Hundley, V. (2002). Getting your paper to the right journal: a case study of an academic paper. Journal of Advanced Nursing, 37(6), 506-511.

- Venuti, L. (1994). Translation and the Formation of Cultural Identities. Current Issues in Language and Society, 1(3), 201-207.

- Venuti, L. (2009). Translation, Intertextuality, Interpretation. Romance Studies, 27(3), 157-173.

- Web of Science. (2014). Available at: http://wokinfo.com/

Table 1 Impact of TS journals according to different bibliometric tools

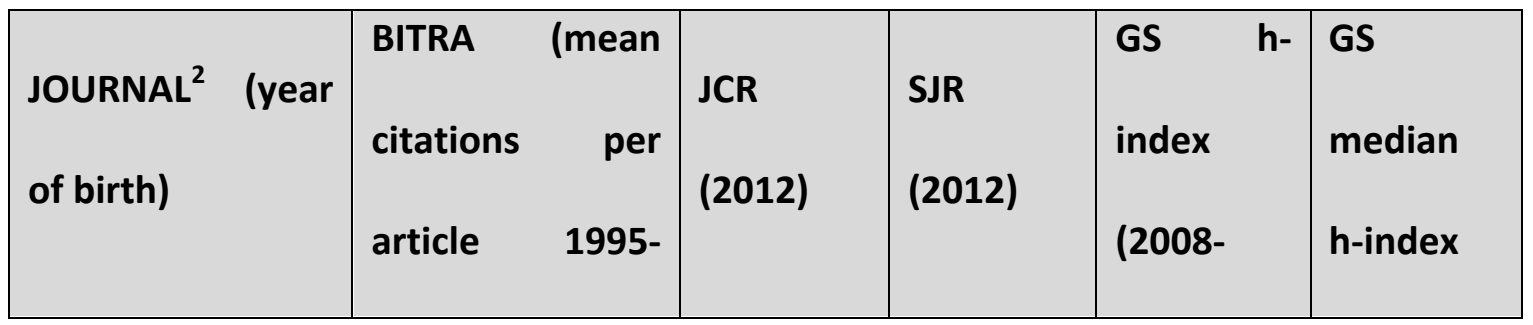

\footnotetext{
2 Journals' subtitles are not shown in this table.
} 


\begin{tabular}{|c|c|c|c|c|c|}
\hline & 2012) & & & 2012) & $\begin{array}{l}\text { (2008- } \\
\text { 2012) }\end{array}$ \\
\hline Target (1989) & 4.0 & $0.074(\mathrm{Q} 4)$ & $0.101(Q 4)$ & 7(Q2) & 10 \\
\hline $\begin{array}{l}\text { The Translator } \\
\text { (1995) }\end{array}$ & 3.9 & $0.667(\mathrm{Q} 2)$ & $0.126(\mathrm{Q} 3)$ & $8(\mathrm{Q} 1)$ & 13 \\
\hline $\begin{array}{l}\text { Interpreting } \\
\text { (1996) }\end{array}$ & 3.1 & $0.095(Q 4)$ & $0.112(\mathrm{Q} 3)$ & - & - \\
\hline $\begin{array}{l}\text { Across } \\
\text { Languages \& } \\
\text { Cultures (2000) }\end{array}$ & 1.5 & $0(Q 4)$ & $0.132(Q 3)$ & - & - \\
\hline Meta (1956) & 1.5 & - & $0.117(\mathrm{Q} 3)$ & $7(\mathrm{Q} 2)$ & 10 \\
\hline TTR (1988) & 0.9 & - & $0.101(\mathrm{Q} 4)$ & $3(Q 3)$ & 6 \\
\hline $\begin{array}{l}\text { Perspectives } \\
\text { (1993) }\end{array}$ & 0.7 & - & $0.203(Q 2)$ & - & - \\
\hline Babel (1955) & 0.6 & - & $0.101(\mathrm{Q} 4)$ & $5(Q 2)$ & 6 \\
\hline Quaderns (1998) & 0.6 & - & $0.101(\mathrm{Q} 3)$ & $5\left(Q_{2}\right)$ & 7 \\
\hline $\begin{array}{l}\text { Cadernos de } \\
\text { Traduçao (1996) }\end{array}$ & 0.2 & - & - & - & - \\
\hline
\end{tabular}

Appendix

Translation Studies living journals as of May 2014

\begin{tabular}{|l|l|l|l|}
\hline Journal Name & $\begin{array}{l}\text { st } \\
\text { year }\end{array}$ & Publisher / Country & $\begin{array}{l}\text { Open } \\
\text { / Toll } \\
\text { Acce } \\
\text { ss }\end{array}$ \\
\hline
\end{tabular}




\begin{tabular}{|c|c|c|c|}
\hline 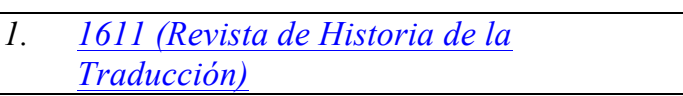 & 2007 & U. Autònoma de Barcelona (Spain) & $\mathrm{OA}$ \\
\hline 2. Across Languages and Cultures & 2000 & Akadémiai Kiadó (Hungary) & TA \\
\hline Atelier de traduction & 2004 & U. Stefan cel Mare Suceava (Romania) & $\mathrm{OA}$ \\
\hline Babel & 1955 & John Benjamins (Netherlands) & TA \\
\hline Babilonia & 2003 & Eds. Univ. Lusófonas (Portugal) & TA \\
\hline Cadernos de Literatura em Tradução & 1997 & CITRAT \& ABRAPT (Brazil) & $\mathrm{OA}$ \\
\hline Cadernos de Tradução & 1996 & U. Federal de Santa Catarina (Brazil) & $\mathrm{OA}$ \\
\hline 8. $\quad \begin{array}{l}\text { Chinese Translators Journal }=\text { Zhongguo } \\
\text { fanyi }\end{array}$ & 1991 & Translators Assoc. of China (China) & TA \\
\hline Communicate! & 1999 & AIIC & $\mathrm{OA}$ \\
\hline 10. Compilation and Translation Review & 2008 & $\begin{array}{l}\text { National Academy for Educational } \\
\text { Research (Taiwan) }\end{array}$ & TA \\
\hline 11. $\frac{\text { Cultus. The Journal of Intercultural }}{\text { Mediation and Communication }}$ & 2008 & Self-publication (Italy) & TA \\
\hline 12. $\frac{\text { Doletiana. Revista de traducció, literatura }}{\text { i arts }}$ & 2007 & U. Autònoma de Barcelona (Spain) & $\mathrm{OA}$ \\
\hline 13. ENTRECULTURAS & 2009 & U. de Málaga (Spain) & $\mathrm{OA}$ \\
\hline 14. $\underline{\text { Equivalences }}$ & 1970 & $\begin{array}{l}\text { Institut Supérieur de Traduction et } \\
\text { d'Interprètes de Bruxelles (Belgium) }\end{array}$ & TA \\
\hline Estudios de traducción & 2011 & U. Complutense de Madrid (Spain) & $\mathrm{OA}$ \\
\hline 16. $\frac{\text { Fan I Hsueh Yen Chiu Chi Kan }=\text { Studies }}{\text { of Translation and Interpretation }}$ & 1996 & $\begin{array}{l}\text { Taiwan Association of Translation and } \\
\text { Interpretation (Taiwan) }\end{array}$ & TA \\
\hline 17. Fordítástudomány & 1999 & Scholastica (Hungary) & $\mathrm{OA}$ \\
\hline 18. Forum & 2003 & $\begin{array}{l}\text { Sorbonne Nouvelle \& Korean Soc. of } \\
\text { Conf. Interpretation (France \& Korea) }\end{array}$ & TA \\
\hline 19. $\frac{\text { Guang Yi: Lingual, Literary, and Cultural }}{\text { Translation }}$ & 2008 & National Chengchi U. (China) & TA \\
\hline 20. Hikma & 2002 & U. de Córdoba (Spain) & TA \\
\hline Hermeneus & 1999 & U. de Valladolid (Spain) & $\mathrm{OA}$ \\
\hline 22. $\begin{array}{l}\text { Hermes - Journal of Language and } \\
\text { Communication Studies }\end{array}$ & 1988 & Aarhus U. (Danemark) & $\mathrm{OA}$ \\
\hline 23. $\frac{\text { IJ-ELTS (International Journal of English }}{\text { Language and Translation Studies) }}$ & 2013 & Lasting Impressions Press (Libya) & $\mathrm{OA}$ \\
\hline Ikala & 1996 & U. de Antioquia (Colombia) & $\mathrm{OA}$ \\
\hline $\begin{array}{l}\text { 25. In Other Words: The Journal for Literary } \\
\text { Translators }\end{array}$ & 1993 & $\begin{array}{l}\text { British Centre for Literary Translation } \\
\text { (United Kingdom) }\end{array}$ & TA \\
\hline 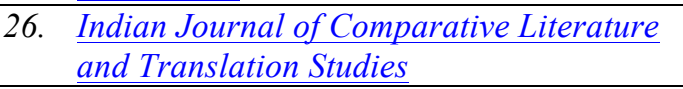 & 2013 & U. of Hyderabad (India) & TA \\
\hline 27. $\frac{\text { International Journal of Interpreter }}{\text { Education }}$ & 2009 & CIT (USA) & TA \\
\hline 28. International Journal of Translation & 1989 & Bahri Publications (India) & TA \\
\hline $\begin{array}{l}\text { 29. } \frac{\text { Interpreting. International Journal of }}{\text { Research and Practice in Interpreting }} \\
\text { Re }\end{array}$ & 1996 & John Benjamins (Netherlands) & TA \\
\hline inTRAlinea & 1998 & U. degli Studi di Bologna (Italia) & $\mathrm{OA}$ \\
\hline ITI Bulletin & 1988 & ITI (United Kingdom) & TA \\
\hline 32. $\frac{\text { Jostrans - The Journal of Specialised }}{\text { Translation }}$ & 2004 & Self-publication (United Kingdom) & OA \\
\hline Journal of Interpretation (JOI) & 1988 & RID (USA) & TA \\
\hline 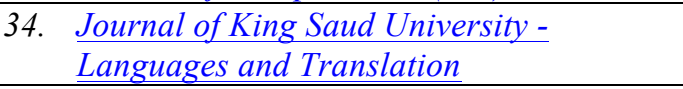 & 1997 & King Saud U. (Saudi Arabia) & TA \\
\hline Journal of Translation & 2005 & SIL (USA) & TA \\
\hline 36. $\frac{\text { Journal of Translation Studies }=\text { Fanyi }}{\text { Xuebao }}$ & 1997 & Chinese U. of Hong Kong (China) & TA \\
\hline L'interprète & 1946 & AIT (Switzerland) & TA \\
\hline La linterna del traductor & 2002 & ASETRAD (Spain) & $\mathrm{OA}$ \\
\hline 39. $\frac{\text { Language and Translation }=\text { Yuyan } \mathrm{Yu}}{\text { Fanyi }}$ & 1985 & Language Work Committee (China) & TA \\
\hline 40. Languages and Translation & 2010 & European Union & $\mathrm{OA}$ \\
\hline
\end{tabular}




\begin{tabular}{|c|c|c|c|}
\hline 41. Languages in Contrast & 1998 & John Benjamins (Netherlands) & TA \\
\hline 42. $\frac{\text { LANS - Linguistica Antverpiensia New }}{\text { Series }}$ & 2002 & $\begin{array}{l}\text { Hoger Instituut Vertalers \& Tolken } \\
\text { (Belgium) }\end{array}$ & $\mathrm{OA}$ \\
\hline 43. Lebende Sprachen & 1956 & Langenscheidt (Germany) & TA \\
\hline 44. Letras & 1979 & U. Nacional de C. Rica (Costa Rica) & $\mathrm{OA}$ \\
\hline Localisation Focus & 1996 & U. of Limerick (United Kingdom) & TA \\
\hline Machine Translation & 1989 & Kluwer (Germany) & TA \\
\hline 47. Miedzy oryginalem a przekladem & 1995 & $\begin{array}{l}\text { Tow. Autorów i Wydawców Prac } \\
\text { Nauk. U. (Poland) }\end{array}$ & TA \\
\hline 48. mediAzioni & 2005 & U. di Bologna sede di Forli (Italia) & $\mathrm{OA}$ \\
\hline 49. Meta & 1956 & U. de Montréal & $\mathrm{OA}$ \\
\hline 50. $\frac{\text { MonTI (Monographs in Translation \& }}{\text { Interpreting) }}$ & 2009 & $\begin{array}{l}\text { U. Alicante, Jaume I \& U. València } \\
\text { (Spain) }\end{array}$ & $\mathrm{OA}$ \\
\hline $\begin{array}{l}\text { 51. } \\
\text { mTm - Minor Translating Major - Major } \\
\text { Translating Minor - Minor }\end{array}$ & 2009 & Diavlos Books (Greece) & TA \\
\hline 52. Multilingua & 1982 & De Gruyter (Germany) & TA \\
\hline 53. Multilingual Computing \& Technology & 1988 & MultiLingual Computing Inc. (Ireland) & TA \\
\hline 54. Mutatis Mutandis & 2008 & U. de Antioquia (Colombia) & $\mathrm{OA}$ \\
\hline New Voices in Translation Studies & 2005 & IATIS \& CTTS (Ireland) & $\mathrm{OA}$ \\
\hline $\begin{array}{l}\text { 56. Onomázein: Revista de Lingüistica, } \\
\text { Filología y Traducción } \\
\end{array}$ & 1996 & Pontificia U. Católica de Chile (Chile) & $\mathrm{OA}$ \\
\hline 57. Palimpsestes & 1983 & Sorbonne Nouvelle (France) & TA \\
\hline 58.Panace@ & 2000 & MedTrad (Spain) & $\mathrm{OA}$ \\
\hline 59. Parallèles & 1978 & U. de Genève (Switzerland) & TA \\
\hline Perspectives: Studies in Translatology & 1993 & Taylor \& Francis (United Kingdom) & TA \\
\hline Puentes & 2002 & GRETI, AVANTI \& Atrio (Spain) & $\mathrm{OA}$ \\
\hline Puntoycoma & 1991 & Traductores españoles de la UE & $\mathrm{OA}$ \\
\hline 63. Quaderns, Revista de Traducció & 1998 & U. Autònoma de Barcelona (Spain) & $\mathrm{OA}$ \\
\hline 64. Redit & 2008 & U. de Málaga (Spain) & $\mathrm{OA}$ \\
\hline Renditions & 1973 & Chinese U. of Hong Kong (China) & TA \\
\hline Scientia Traductionis & 2005 & U. Federal de Santa Catarina (Brazil) & $\mathrm{OA}$ \\
\hline 67. $\frac{\text { Shanghai Fanyi }=\text { Shanghai Journal of }}{\text { Translators }}$ & 2001 & $\begin{array}{l}\text { Shanghai Science and Technology } \\
\text { Translators Society (China) }\end{array}$ & TA \\
\hline 68. SKASE & 2005 & SKASE \& Presov University (Slovakia) & $\mathrm{OA}$ \\
\hline 69. Skopos & 2012 & U. de Córdoba (Spain) & $\mathrm{OA}$ \\
\hline Sendebar & 1990 & U. de Granada (Spain) & $\mathrm{OA}$ \\
\hline Senez & 1984 & Eizie (Spain) & $\mathrm{OA}$ \\
\hline Septet & 2008 & SEPTET \& Eds. Anagrammes (France) & TA \\
\hline T21N. Translation in Transition & 2010 & U. Heidelberg (Germany) & $\mathrm{OA}$ \\
\hline 74. $\quad$ Target & 1989 & John Benjamins (Netherlands) & TA \\
\hline 75. The AALITRA Review & 2010 & AALITRA \& Monash U. (Australia) & $\mathrm{OA}$ \\
\hline $\begin{array}{l}\text { 76. } \\
\text { The Interpreter and Translator Trainer } \\
\text { (ITT) }\end{array}$ & 2007 & Taylor \& Francis (United Kingdom) & TA \\
\hline The Interpreters' Newsletter & 1988 & U. degli Studi di Trieste (Italy) & $\mathrm{OA}$ \\
\hline 78. The Bible Translator & 1950 & United Bible Societies (USA) & TA \\
\hline 79. The Translator & 1995 & Taylor \& Francis (United Kingdom) & TA \\
\hline 80. TIS (Translation and Interpreting Studies) & 2006 & ATISA \& J. Benjamins (Netherlands) & TA \\
\hline$T C 3$ & 2011 & U. Mainz (Germany) & $\mathrm{OA}$ \\
\hline Terminology & 1994 & John Benjamins (Netherlands) & $\mathrm{TA}$ \\
\hline Testo a fronte & 1989 & Marcos y Marcos (Italy) & TA \\
\hline 84. $\quad$ TradTerm & 1994 & $\begin{array}{l}\text { CITRAT, FFCLH \& U. São Paulo } \\
\text { (Brazil) }\end{array}$ & $\mathrm{OA}$ \\
\hline 85. Traduire & 1952 & Soc. Française des Traducteurs (France) & TA \\
\hline Tradução e comunicação & 1981 & Centro U. Anhanguera S. Paulo (Brazil) & $\mathrm{OA}$ \\
\hline 87. $\quad$ Tradução em revista & 2004 & $\begin{array}{l}\text { Pontifícia U. Católica do Rio de Janeiro } \\
\text { (Brazil) }\end{array}$ & $\mathrm{OA}$ \\
\hline 88. Tradumàtica: Tecnologies de la traducció & 2001 & $\begin{array}{l}\text { U. Autònoma de Barcelona, U. Pompeu } \\
\text { Fabra \& U. de Vic (Spain) }\end{array}$ & $\mathrm{OA}$ \\
\hline
\end{tabular}




\begin{tabular}{|l|l|l|l|}
\hline 89. Tradurre. Pratiche teorie strumenti & 2011 & Self-publication (Italy) & OA \\
\hline 90. Trans. Revista de traductología & 1996 & U. de Málaga & OA \\
\hline 91. trans-kom & 2008 & Frank \& Timme (Germany) & OA \\
\hline 92. Transfer & 2006 & U. Autònoma de Barcelona (Spain) & OA \\
\hline 93. TranscUlturAl & 2008 & U. of Alberta (Canada) & OA \\
\hline 94. Translating Today Magazine & 2004 & Self-publication & OA \\
\hline 95. Translatio & 1981 & FIT (Belgium) & TA \\
\hline 96. Translation. A Transdisciplinary Journal & 2012 & Nida School of Transl. Studies (Italy) & OA \\
\hline 97. Translation and Literature & 1992 & Edinburgh U. (United Kingdom) & TA \\
\hline 98. Translation \& Interpreting & 2009 & U. of Western Sydney (Australia) & OA \\
\hline 99. Translation Ireland & 1987 & ITIA (Ireland) & TA \\
\hline 100. Translation Journal & 1997 & Self-Publication (USA) & OA \\
\hline 101. Translation Quarterly & 1995 & Hong Kong Translation Society (China) & TA \\
\hline 102. Translation Review & 1978 & $\begin{array}{l}\text { ALTA \& Taylor \& Francis (United } \\
\text { Kingdom) }\end{array}$ & TA \\
\hline 103. Translation Spaces & 2012 & John Benjamins (Netherlands) & TA \\
\hline 104. Translation Studies & 2008 & Taylor \& Francis (United Kingdom) & TA \\
\hline 105. Translationes & 2009 & U. de Vest (Romania) & OA \\
\hline 106. TTR traduction, terminologie, redaction) & 1988 & CATS (Canada) & OA \\
\hline 107. Turjuman: revue de traduction et & 1992 & $\begin{array}{l}\text { Ecole Supérieure Roi Fahd de } \\
\text { Traduction (Morocco) }\end{array}$ & TA \\
\hline d'interprétation & 2012 & York U. (Canada) & OA \\
\hline 108. Tusaaji: A Translation Review & 2009 & Center for the Art of Translation (USA) & OA \\
\hline 109. Two Lines: A Journal of Translation & 1993 & ACE Traductores (Spain) & OA \\
\hline 110. Vasos comunicantes & 1995 & $\begin{array}{l}\text { Asociación de Traductores Galegos \& } \\
\text { U. de Vigo (Spain) }\end{array}$ & OA \\
\hline 111. Viceversa & 1988 & $\begin{array}{l}\text { China National Knowledge } \\
\text { Infrastructure (CNKI) (China) }\end{array}$ & TA \\
\hline 112. Zhongguo Keji Fanyi = Chinese Science \& \\
\hline Technology Translators Journal & & & \\
\hline
\end{tabular}

